\title{
Holocene Asian monsoon evolution revealed by a pollen record from an alpine lake on the southeastern margin of the Qinghai-Tibetan Plateau, China
}

\author{
Enlou Zhang ${ }^{1}$, Yongbo Wang ${ }^{2}$, Weiwei Sun ${ }^{1,3}$, and Ji Shen ${ }^{1}$ \\ ${ }^{1}$ State Key Laboratory of Lake Science and Environment, Nanjing Institute of Geography and Limnology, \\ Chinese Academy of Sciences, Nanjing 210008, China \\ ${ }^{2}$ College of Resource Environment and Tourism, Capital Normal University, Beijing 100048, China \\ ${ }^{3}$ University of Chinese Academy of Sciences, Beijing 100049, China
}

Correspondence to: Enlou Zhang (elzhang@niglas.ac.cn), Ji Shen (jishen@niglas.ac.cn)

Received: 1 September 2015 - Published in Clim. Past Discuss.: 8 October 2015

Revised: 12 January 2016 - Accepted: 5 February 2016 - Published: 23 February 2016

\begin{abstract}
We present the results of pollen analyses from a $1105 \mathrm{~cm}$ long sediment core from Wuxu Lake in southwestern China, which depict the variations of the East Asian winter monsoon (EAWM) and the Indian summer monsoon (ISM) during the last $12.3 \mathrm{ka}$. During the period of 12.3 to $11.3 \mathrm{cal} \mathrm{kaBP}$, the dominance of Betula forest and open alpine shrub and meadow around Wuxu Lake indicates a climate with relatively cold winters and dry summers, corresponding to the Younger Dryas event. Between 11.3 and $10.4 \mathrm{cal} \mathrm{ka} \mathrm{BP}$, further expansion of Betula forest and the retreat of alpine shrubs and meadows reflect a greater seasonality with cold winters and gradually increasing summer precipitation. From 10.4 to $4.9 \mathrm{cal} \mathrm{kaBP}$, the dense forest understory, together with the gradual decrease in Betula forest and increase in Tsuga forest, suggest that the winters became warmer and summer precipitation was at a maximum, corresponding to the Holocene climatic optimum. Between 4.9 and $2.6 \mathrm{cal} \mathrm{ka} \mathrm{BP,} \mathrm{Tsuga} \mathrm{forest} \mathrm{and} \mathrm{alpine} \mathrm{shrubs} \mathrm{and} \mathrm{mead-}$ ows expanded significantly, reflecting relatively warm winters and decreased summer precipitation. Since $2.6 \mathrm{cal} \mathrm{ka} \mathrm{BP,}$ reforestation around Wuxu Lake indicates a renewed humid period in the late Holocene; however, the vegetation in the catchment may also have been affected by grazing activity during this period. The results of our study are generally consistent with previous findings; however, the timing and duration of the Holocene climatic optimum from different records are inconsistent, reflecting real contrast in local rainfall response to the ISM. Overall, the EAWM is broadly in-
\end{abstract}

phase with the ISM on the orbital timescale, and both monsoons exhibit a trend of decreasing strength from the early to late Holocene, reflecting the interplay of solar insolation receipt between the winter and summer seasons and El NiñoSouthern Oscillation strength in the tropical Pacific.

\section{Introduction}

As an important component of the global climate system, the Asian summer monsoon, including Indian and East Asian summer monsoon systems, significantly affects sustainable development and ecosystem dynamics within a large, densely populated region (An et al., 2000). During the last two decades, the variability of the Indian summer monsoon (ISM) in the Holocene has been reconstructed from various types of paleoclimatic archive and proxies, such as stalagmite oxygen isotope $\left(\delta^{18} \mathrm{O}\right)$ records (Cai et al., 2012; Fleitmann et al., 2003, 2007), marine sediments (Contreras-Rosales et al., 2014; Gupta et al., 2003; Rashid et al., 2007), and lake and peatland sediments (Bird et al., 2014; Chen et al., 2014; Cook et al., 2013; Demske et al., 2009; Fuchs and Buerkert, 2008; Jarvis, 1993; Kramer et al., 2010; Prasad et al., 2014; Sarkar et al., 2015; Shen et al., 2006; C. Shen et al., 2006; J. Shen et al., 2005; Song et al., 2012; Sun et al., 2015; Xiao et al., 2014a). Among the numerous records, stalagmites can be accurately and precisely dated using $\mathrm{U}$-series methods (Cheng et al., 2000). The stalagmite $\delta^{18} \mathrm{O}$ results from various sites indicate a uniform evolution history with the optimum cli- 
mate occurring in the early Holocene. However, stalagmite $\delta^{18} \mathrm{O}$ values are also influenced by seasonality of precipitation, moisture source and transport pathway, especially in eastern China (Breitenbach et al., 2010; Maher, 2008; Maher and Thompson, 2012; Pausata et al., 2011; Tan, 2014; Wang et al., 2001). In contrast, the timing and duration of the Holocene climatic optimum inferred from marine and lake sediment records differ from the speleothem record, possibly because of differences in temporal resolution, in the sensitivity of the proxy, and the lack of reliable chronologies (Hou et al., 2012; Sun et al., 2015; Zhang et al., 2011). In addition, there is also the potential of local differences in ISM precipitation response (Bird et al., 2014), and therefore there is a need for additional detailed paleoclimatic studies in the region.

The East Asian winter monsoon (EAWM), which originates in the Siberian high centered in Mongolia and northeastern Siberia, is the winter counterpart of the Asian summer monsoon in China and is characterized by cold and dry northwesterly or northeasterly winds (Chen et al., 2000). However, high-resolution records of the EAWM for the Holocene are sparse and their interpretation is controversial. Records of Ti concentration, total organic carbon content and magnetic susceptibility from Huguangyan Lake in southern China suggest a strengthening of the EAWM from the early to the late Holocene (Yancheva et al., 2007); however, geochemical and magnetic analyses indicate that the local pyroclastic bedrock is the dominant source of the Huguangyan Lake sediments (Shen et al., 2013; Zhou et al., 2009). In addition, recent studies, based on diatom assemblages and stable nitrogen isotope $\left(\delta^{15} \mathrm{~N}\right)$ analyses of sediments from the same lake, indicate a stronger EAWM in the early Holocene (Jia et al., 2015; Wang et al., 2012). Other proxies for reconstructing Holocene EAWM variability include the grain size distribution of loess deposits and thermocline gradients from the South China Sea, although they are of low temporal resolution (Huang et al., 2011; Steinke et al., 2010, 2011; Stevens et al., 2007; Sun et al., 2012; Tian et al., 2010).

Southwestern China, which mainly includes the YunnanGuizhou Plateau, the Sichuan Basin and the southeastern Qinghai-Tibetan Plateau (QTP), is a typical region which is strongly influenced by the ISM and EAWM (An et al., 2000). Modern pollen data indicate that the mean temperature of the coldest month and annual precipitation are the dominant climatic variables of modern pollen/vegetation distributions in South China (Li et al., 2015). Pollen analysis has been widely used to reconstruct Holocene paleovegetation and paleoclimate in the region (Chen et al., 2014; Cook et al., 2013; Jarvis, 1993; Kramer et al., 2010; C. Shen et al., 2006; J. Shen et al., 2006; Song et al., 2012; Xiao et al., 2014a). However, in most of these records the chronology is based on radiocarbon dating of bulk organic matter and/or is of low resolution.

Wuxu Lake is an alpine lake in the mountainous region of the southeastern QTP. The altitude is about $3706 \mathrm{~m}$ a.s.l.
(Xiao et al., 2011), and close to the elevation of the present tree-line in the region, which increases the sensitivity of vegetation to climate change. Here we present a Holocene pollen record from the lake sediments, and use it to reconstruct the history of regional vegetation and climate changes, and thus the evolution of the ISM and EAWM.

\section{Study site}

Wuxu Lake $\left(29^{\circ} 9^{\prime} 11.48 \mathrm{~N}, 101^{\circ} 24^{\prime} 21.6 \mathrm{E}\right)$ is located in an eastern branch of the Hengduan Mountains on the southeastern margin of the QTP (Fig. 1a). The southeastern margin of the QTP is characterized by steep valley-ridge relief, characterized by parallel, deep and narrowly incised river valleys such as Dadu River, Yalong River and Jinsha River. The elevation ranges from 1500 to above $5000 \mathrm{~m}$ a.s.l., resulting in steep climatic gradients in the region. Mean summer (from June to August) temperature ranges from 5 to $21^{\circ} \mathrm{C}$, and mean annual precipitation varies between 500 and $1200 \mathrm{~mm}$ (Yu et al., 2001). The regional vegetation includes warm temperate evergreen broad-leaved forest in the foothills, cool evergreen coniferous forest extending up to $4400 \mathrm{~m}$ a.s.l., and alpine shrubs and meadows in the cold, high-elevation regions below the permanent snowline (Wu et al., 1980).

Wuxu Lake has an area of $0.5 \mathrm{~km}^{2}$ with a catchment area of $6.5 \mathrm{~km}^{2}$ (Wischnewski et al., 2011). The maximum water depth is $30.8 \mathrm{~m}$ (Wischnewski et al., 2011). The lake is fed mainly by a single stream which enters on the northwest side of the lake and has a single outflow in the southeast, which flows into the Jiulong River and then into the Yalong River (Fig. 1b). The closest weather station is Litang Station at $3948 \mathrm{~m}$ a.s.1., which records a mean July temperature of $10.5^{\circ} \mathrm{C}$, mean January temperature of $-6^{\circ} \mathrm{C}$, and mean annual precipitation of $720 \mathrm{~mm}$ which mainly occurs in the rainy season from May to September (Wischnewski et al., 2011). The vegetation around the lake is dominated by Picea likiangensis, Abies squamata, Quercus aquifoliodes and Quercus pamosa with Betula utilis, Betula platyphylla, Salix and Rhododendron occurring in the secondary canopy. The forest is gradually replaced by sub-alpine Rhododendron shrubs and alpine meadows with increasing altitude. At present the catchment is little disturbed by human activity. Occasionally, Tibetan yak herdsmen use the area as grazing grounds during summer.

\section{Materials and methods}

\subsection{Sediment sampling and dating}

In summer 2010, we obtained a $1105 \mathrm{~cm}$ long sediment core from the deepest part of Wuxu Lake (30 m depth) using a UWITEC piston corer. The core was sub-sampled at $1 \mathrm{~cm}$ contiguous intervals and stored at $4{ }^{\circ} \mathrm{C}$ prior to analysis. The chronology is based on accelerator mass spectrometry (AMS) ${ }^{14} \mathrm{C}$ dates from terrestrial plant macrofossils ex- 


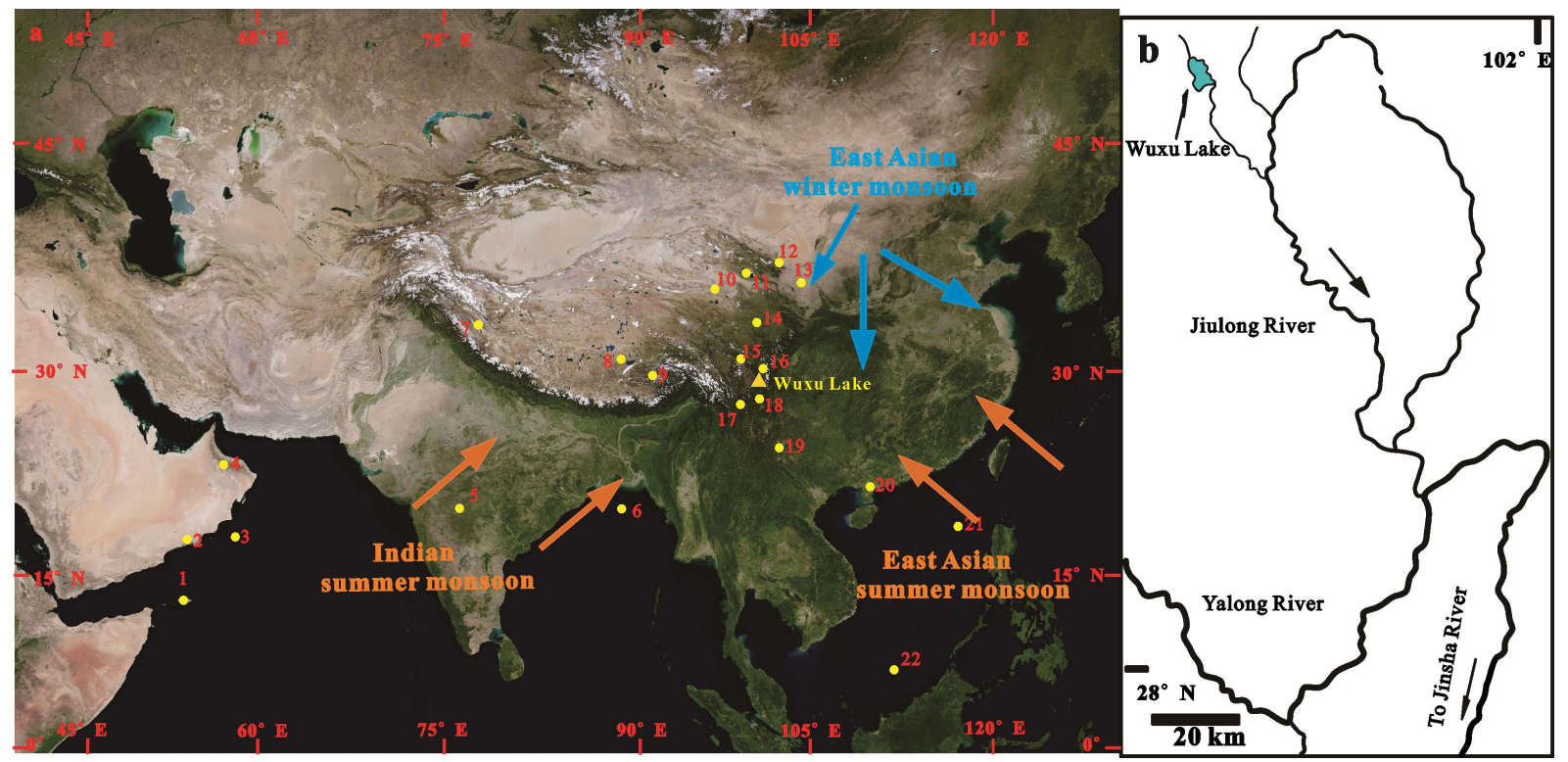

Figure 1. (a) Location of Wuxu Lake in monsoonal Asia (yellow triangle) and of the paleoclimate sites mentioned in the text (yellow circles); and the dominant circulation systems of the Indian summer monsoon, East Asian summer monsoon and the East Asian winter monsoon. 1, Moomi Cave (Shakun et al., 2007); 2, Qunf Cave (Fleitmann et al., 2003); 3, Hoti Cave (Fleitmann et al., 2007); 4, Lonar Lake (Prasad et al., 2014; Sarkar et al., 2015); 5, Core SO188-342KL (Contreras-Rosales et al., 2014); 6, Tso Kar (Demske et al., 2009); 7, Tianmen Cave (Cai et al., 2012); 8, Paru Co (Bird et al., 2014); 9, Gonghe Basin (Liu et al., 2013); 10, Gulang profile (Sun et al., 2012); 11, Jingyuan profile (Sun et al., 2012); 12, Naleng Lake (Kramer et al., 2010); 13, Tiancai Lake (Xiao et al., 2014b); 14, Xingyun Lake (Chen et al., 2014); 15, Huguangyan Lake (Jia et al., 2015; Wang et al., 2012); 16, Core MD05-2904 (Steinke et al., 2011); 17, Core MD01-2390 (Steinke et al., 2010). (b) Expanded view of the study area.

tracted from the sediment samples. The analyses were made by Beta Analytic Inc. in Miami, USA and the Rafter Radiocarbon Laboratory in the Institute of Geological and $\mathrm{Nu}$ clear Sciences, New Zealand. All of the $18 \mathrm{AMS}^{14} \mathrm{C}$ dates obtained were calibrated to calendar years before present $(0 \mathrm{BP}=1950 \mathrm{AD})$ using the program Calib 7.1 and the IntCal13 calibration data set (Reimer et al., 2013).

\subsection{Pollen analysis}

Samples for pollen analysis were determined at $4 \mathrm{~cm}$ intervals and treated using standard laboratory methods (Fægri et al., 1989), including treatment with $\mathrm{HCl}$ and $\mathrm{HF}$ to remove carbonate and silicate, boiling in $\mathrm{KOH}$ to remove humic acid, sieving with 10 and $120 \mu \mathrm{m}$ mesh clothes to remove the fine and coarse fractions, respectively, and mounting in silicone oil. Prior to these treatments, tablets containing a known quantity of Lycopodium spores were added to each sample in order to determine the pollen concentration. At least 500 terrestrial pollen grains per sample were counted. The percentage for each pollen type was calculated based on the sum of total terrestrial pollen; pollen and spores from aquatic plants and ferns were excluded from the calculation.

\subsection{Data treatment and statistical analyses}

The pollen diagram was divided into biostratigraphic zones based on constrained incremental sum of squares (CONISS) using the Tilia program (Grimm, 1987). CONISS uses an algorithm based on stratigraphically constrained chorddistance clustering and square-root transformation of the pollen percentage data. Only pollen taxa with a representation $>1 \%$ in at least two samples were included in the zonation.

In order to identify and visualize the main directions of vegetation change, 31 terrestrial pollen types with a representation $>1 \%$ in at least two samples were included in an ordination analysis. Pinus pollen is considered to be transported from the lowest-altitude vegetation zone in the region, or from long-distance sources. Its percentage values are the highest of all of the taxa recorded and they do not exhibit any obvious change; therefore, its weighting was set to 0.1 in the numerical analysis (Xiao et al., 2014a). Detrended correspondence analysis (DCA) yielded gradients of 1.03 standard deviations for the pollen data set, indicating that linear-based methods such as principal component analysis (PCA) are appropriate for the data set. The PCA analysis was applied to the square-root-transformed pollen data for inter-species correlations. The DCA and PCA analyses were performed using the CANOCO program 4.5 (ter Braak and Šmilauer, 2002). 


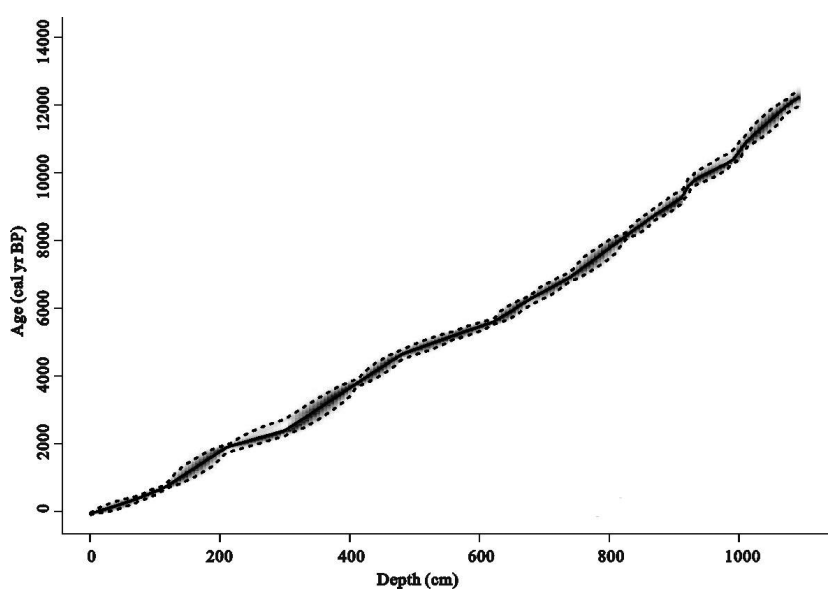

Figure 2. Age-depth model for the Wuxu Lake sediment core produced by Bacon software. The dotted lines indicate the $95 \%$ confidence limits and the solid line shows the weighted mean ages for each depth (Blaauw and Andres Christen, 2011; R Development Core Team, 2013).

\section{Results and interpretation}

\subsection{Chronology}

The results of AMS ${ }^{14} \mathrm{C}$ radiocarbon dating of the Wuxu Lake plant remains are shown in Table 1. The results indicate a roughly linear age-versus-depth relationship and therefore that the sediment accumulation rate was relatively constant. A Bayesian model, taking the sediment accumulation rates into account (Blaauw and Andres Christen, 2011), was used to construct the age-depth model (Fig. 2). The model was determined using the default settings for lake sediments at $10 \mathrm{~cm}$ intervals implemented using the statistical software package R (R Development Core Team, 2013). The basal age is about $12.3 \mathrm{cal} \mathrm{kaBP}$, yielding an average sediment accumulation rate of $89.5 \mathrm{~cm} \mathrm{ka}^{-1}$, and thus the average temporal sampling resolution is about 45 years for the pollen record.

\subsection{Pollen assemblages}

A total of 214 pollen and spore types were identified, including 118 arboreal taxa, 40 herbaceous taxa and 20 fern taxa. The entire pollen record is dominated by arboreal taxa, including Pinus, sclerophyllous Quercus, Picea/Abies and Betula, with contributions of Alnus, Tsuga, Lithocarpus/Castanea, Cupressaceae, deciduous Quercus and Ericaceae. The average percentage of the main herbaceous taxa, including Artemisia, Gramineae, Rosaceae, Ranunculaceae, Thalictrum, Labiatae, Gesneriaceae and Cyperaceae, is $18.4 \%$. The pollen spectra can be divided into five assemblage zones according to the changes in terrestrial pollen percentages (Fig. 3).

In Zone I (12.3-11.3 cal ka BP), arboreal taxa account for more than $70 \%$ of total terrestrial pollen, among which Pinus, sclerophyllous Quercus and Betula predominate. Other common taxa include deciduous Quercus, and Picea/Abies. The zone is also characterized by the high abundance of herbaceous taxa, including Artemisia, Cyperaceae, Gramineae and Thalictrum, which all exhibit highest percentages throughout the entire record. Carpinus and Picea/Abies maintain at high abundances within the zone, while Betula exhibits a generally increasing trend.

A notable feature of Zone II (11.3-10.4 cal ka BP) is the abrupt decrease in herbaceous taxa to the benefit of arboreal taxa. Artemisia and Cyperaceae fall from 10 to $5 \%$, and Gramineae and Thalictrum from 5 to $2 \%$, respectively. Betula reaches its maximum (generally over $20 \%$ ) for the entire record. Pinus, Picea/Abies and Carpinus exhibit similar percentages as in zone I.

The third zone (Zone III, 10.4-4.9 cal ka BP) is characterized by relative high arboreal pollen percentages of the entire record and is divided into three sub-zones.

Sub-zone III-1 (10.4-8.2 cal ka BP): The percentages of total arboreal and herbaceous pollen are relatively constant; however, Tsuga begins to be continuously represented in the pollen spectra. Shrub taxa such as Actinidiaceae and Rubus increase significantly, while Rosaceae, Potentilla, Gesneriaceae, Labiatae and Hypericum increase slightly. Betula, Thalictrum and Cyperaceae decrease gradually.

Sub-zone III-2 (8.2-6.6 cal ka BP): Herbaceous taxa increase compared to the previous sub-zone, generally resulting from increases in Artemisia, Thalictrum, Ranunculaceae and Cyperaceae. The representation of Carpinus and deciduous Quercus are similar to the previous sub-zone. Betula is gradually replaced by sclerophyllous Quercus, which is the dominant arboreal taxon. Picea/Abies decreases slightly from 5 to $2 \%$, while Tsuga and Taxodiaceae/Cupressaceae exhibit a minor increase.

Sub-zone III-3 (6.6-4.9 cal ka BP): Sclerophyllous Quercus increases slightly at the expanse of Betula, Taxodiaceae/Cupressaceae and Picea/Abies. Actinidiaceae and Rubus return to relatively high values. The percentages of total arboreal pollen increases slightly compared to the previous sub-zone.

The contribution of herbaceous taxa in Zone IV (4.9$2.6 \mathrm{cal} \mathrm{kaBP}$ ) increases up to $30 \%$, as the result of higher percentages of Artemisia, Cyperaceae, Gramineae. Arboreal taxa decrease to around $70 \%$, mainly due to the reduced $\mathrm{Be}$ tula and deciduous Quercus. Tsuga percentages are the highest in the entire record, and Ericaceae and Hippophae increase significantly. There is a slight increase in the representation of Picea/Abies, Alnus and Carpinus.

Overall, the pollen spectra in Zone V (after $2.6 \mathrm{cal} \mathrm{ka} \mathrm{BP}$ ) are similar to those of Zone IV, but with a slightly increased representation of arboreal taxa. Betula continues to decrease, Carpinus and Tsuga decrease slightly, and sclerophyllous and deciduous Quercus increase slightly, to up to 20 and $5 \%$, respectively. But Rosaceae, Potentilla, Gesneriaceae, Labiatae and Hypericum increase slightly, while 
Table 1. AMS radiocarbon dates of terrestrial plant from Wuxu Lake. All of the $\mathrm{AMS}^{14} \mathrm{C}$ dates are calibrated to calendar years before present using the IntCal13 calibration data set (Reimer et al., 2013).

\begin{tabular}{lrlrrr}
\hline Lab number & $\begin{array}{r}\text { Sample depth } \\
(\mathrm{cm})\end{array}$ & Material dated & $\begin{array}{r}{ }^{14} \text { C ages } \\
(\mathrm{yr} \text { BP })\end{array}$ & $\begin{array}{r}\text { Cal year BP } \\
(2 \sigma)\end{array}$ & $\begin{array}{r}\text { Median age } \\
(\text { cal yr BP })\end{array}$ \\
\hline NZA35824 & 76 & Plant remains & $306 \pm 20$ & $303-452$ & 393 \\
NZA35825 & 114 & Plant remains & $785 \pm 20$ & $679-730$ & 704 \\
NZA 35827 & 212 & Plant remains & $1979 \pm 20$ & $1883-1987$ & 1926 \\
Beta 306665 & 296 & Plant remains & $2230 \pm 30$ & $2153-2333$ & 2228 \\
Beta 306666 & 410 & Plant remains & $3510 \pm 30$ & $3698-3865$ & 3777 \\
Beta 306667 & 478 & Plant remains & $4150 \pm 30$ & $4577-4825$ & 4695 \\
NZA 35832 & 557 & Plant remains & $4500 \pm 25$ & $5047-5293$ & 5167 \\
Beta 306668 & 616 & Plant remains & $4790 \pm 30$ & $5470-5593$ & 5517 \\
Beta 306669 & 672 & Plant remains & $5420 \pm 40$ & $6031-6300$ & 6235 \\
Beta 306670 & 732 & Plant remains & $5980 \pm 40$ & $6721-6936$ & 6819 \\
Beta 306671 & 819 & Plant remains & $7240 \pm 40$ & $7978-8162$ & 8059 \\
Beta 306672 & 862 & Plant remains & $7870 \pm 50$ & $8547-8975$ & 8680 \\
Beta 306673 & 904 & Plant remains & $8110 \pm 40$ & $8983-9242$ & 9052 \\
Beta 306674 & 920 & Plant remains & $8790 \pm 50$ & $9601-10145$ & 9816 \\
Beta 306675 & 980 & Plant remains & $9020 \pm 40$ & $9967-10248$ & 10207 \\
Beta 327103 & 1005 & Plant remains & $9580 \pm 40$ & $10741-11121$ & 10934 \\
Beta 327104 & 1065 & Plant remains & $10210 \pm 50$ & $11718-12118$ & 11914 \\
Beta 327105 & 1080 & Plant remains & $10350 \pm 50$ & $12004-12402$ & 12211 \\
\hline
\end{tabular}

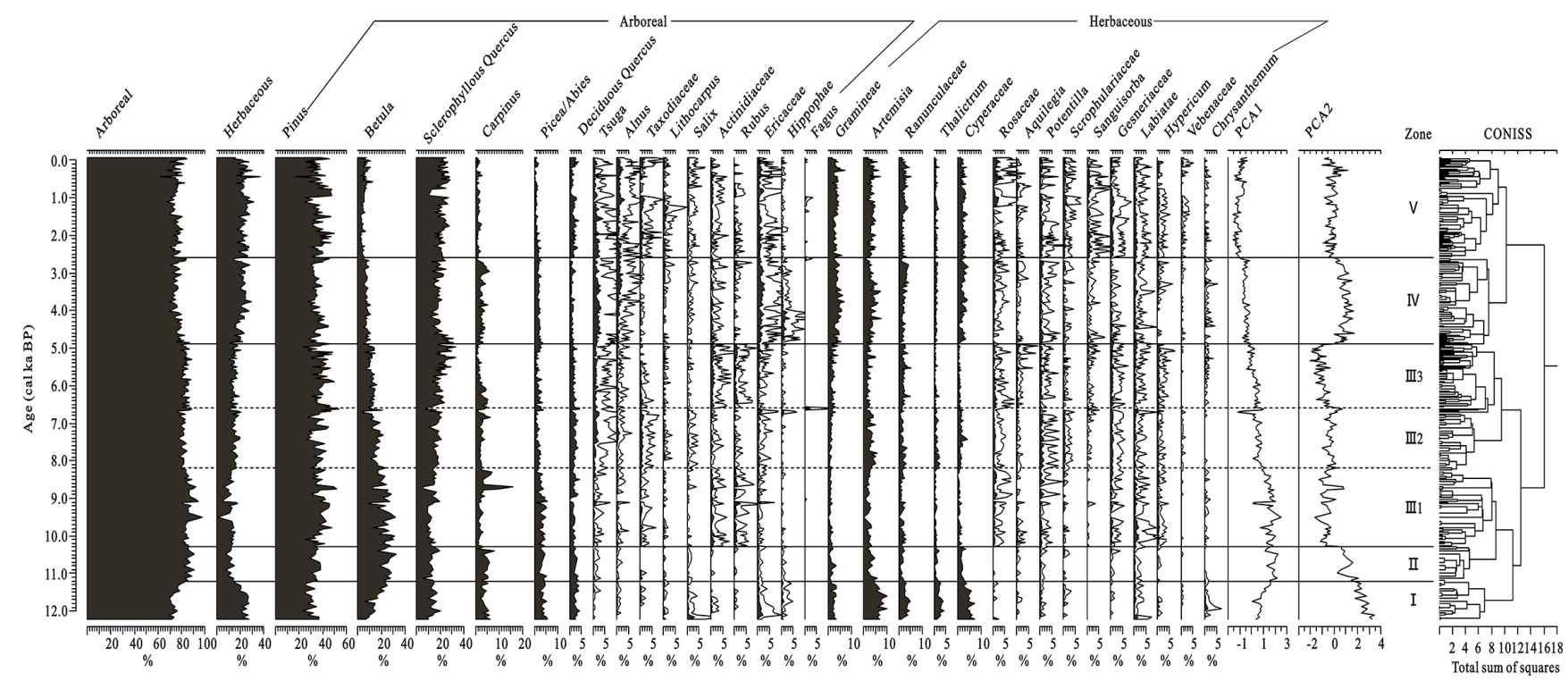

Figure 3. Pollen percentage diagram of selected taxa from the sediment core from Wuxu Lake. Pollen types with relatively low percentages are $\times 5$.

Artemisia, Cyperaceae, Gramineae and Ranunculaceae decrease slightly. It is noteworthy that Sanguisorba increases significantly in this zone.

\subsection{Ordination analysis}

The PCA analysis, based on 31 terrestrial pollen taxa from 276 samples, indicates that the first two axes capture $45.8 \%$ of the total variance, with the first PCA component captur- ing over $33.7 \%$ (Fig. 4a). Three assemblages can be distinguished: alpine shrubs and meadows characterized by Cyperaceae, Artemisia, Polygonum, Thalictrum, Ranunculaceae, Ericaceae, Hippophae and Salix (in the top left quadrant); cool-cold mixed forest characterized by Abies/Picea, Betula, Carpinus and deciduous Quercus (in the top right quadrant); and temperate mixed forest characterized by sclerophyllous Quercus, Tsuga, Alnus, Lithocarpus/Castanopsis, Rubus and Actinidiaceae (in the bottom left quadrant). The ordination 

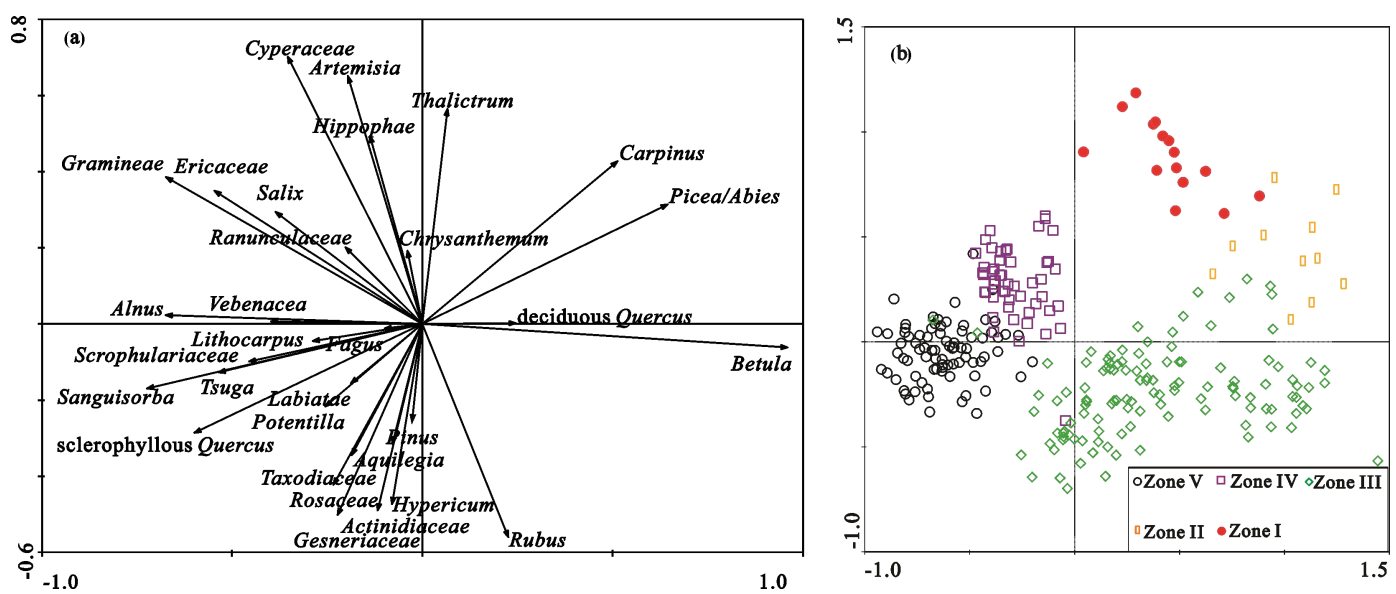

Figure 4. Results of PCA of the pollen percentage data from Wuxu Lake. (a) Variable loadings on the first two principal components. (b) Sample scores on the first two principal components.

of pollen taxa along the first PCA axis apparently reflects a transition from warm to cold winter temperature, since coldtolerant taxa such as Abies/Picea, Betula and other deciduous broadleaved taxa are located on the positive side, while Tsuga, which is sensitive to winter temperature and annual temperature range, is on the negative side (An et al., 2011; Li et al., 2015). The arrangement of the pollen taxa along the second axis separates the major alpine shrub and meadow taxa from the forest taxa, reflecting the degree of openness of the vegetation communities, and can be interpreted as representing a change from dry to more humid conditions. The PCA separates the samples into approximately five groups (Fig. 4b), which generally correspond to the defined pollen zones of the sequence. Samples of zones I, II and III have moderate to high positive scores on the first axis, while samples of zone IV and V have negative scores. Samples of zones I, II and V have high scores on the second axis, while samples of zone III and V have low scores. Spectral analysis was conducted on the PCA axis 2 sample scores using the program REDFIT38 (Schulz and Mudelsee, 2002), and revealed periodicities of 110, 106 and 93 years (significant at the $>90 \%$ confidence level; Fig. 5).

\section{Discussion}

\subsection{Holocene vegetation and climate evolution}

Given the close proximity of Wuxu Lake to the modern treeline, the vegetation around the catchment should react sensitively to climate change. However, lake surface pollen assemblages from the region indicate that large amounts of arboreal pollen, including Pinus, PicealAbies, Betula, deciduous Quercus, Tsuga and evergreen Quercus from the lower vegetation zones, are introduced into sub-alpine and alpine lakes by anabatic winds (Kramer et al., 2010; Xiao et al., 2011). This makes it difficult to use the pollen data to trace

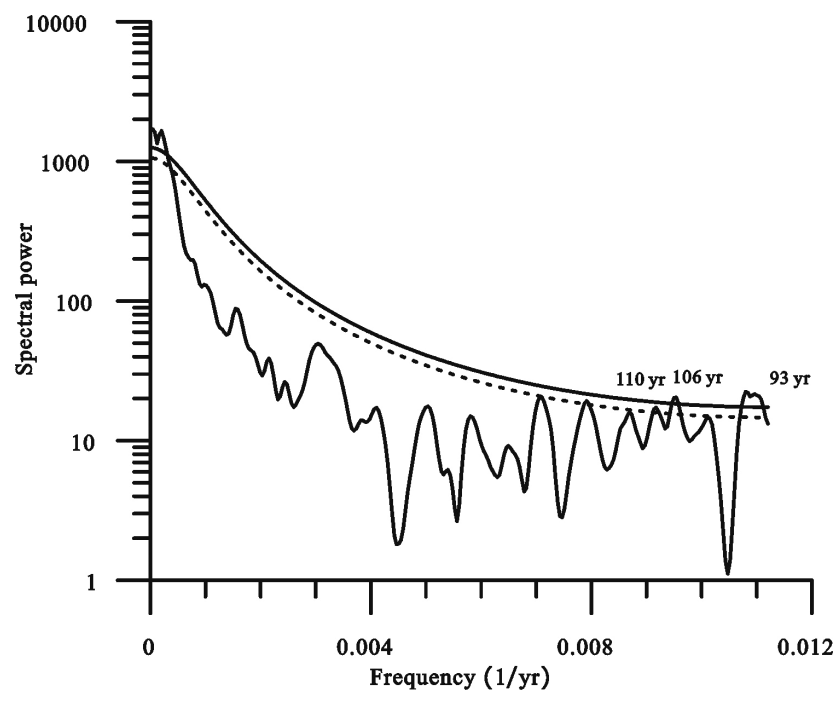

Figure 5. Results of spectral analysis of the PCA 2 axis sample scores of the pollen record from Wuxu Lake over the past $12.3 \mathrm{ka}$. Periodicities which exceed the $90 \%$ confidence level (dashed line) are labeled. Solid line shows the $95 \%$ confidence level.

past fluctuations in the tree-line and the vegetation composition of the catchment. Fortunately, these studies also indicate that the lake surface pollen spectra from different vegetation types still closely correlate with the environmental gradients (Kramer et al., 2010; Xiao et al., 2011). In addition, theoretical models of pollen transport show that the proportion of the non-local pollen component deposited in lake sediments increases with increasing lake size (Jackson and Lyford, 1999; Sugita, 1994). Thus, the pollen assemblages from Wuxu Lake, which is relatively small, should reliably reflect the response of the regional vegetation composition to changes in climate. The inferred changes in vegetation and climate are summarized below. 
The pollen spectra between 12.3 and $11.3 \mathrm{cal} \mathrm{kaBP}$ are characterized by high percentages of Gramineae, Cyperaceae, Artemisia, Polygonum, Thalictrum and Ranunculaceae, with relatively high percentages of Salix, Hippophae and Ericaceae. The high shrub and herbaceous pollen percentages indicate the expansion of alpine shrubs and meadows and open vegetation cover around Wuxu Lake, reflecting weak summer rainfall during the late Younger Dryas (YD). The gradually decreasing herbaceous representation also indicates that the ISM had begun to strengthen. During this period, the surrounding arboreal vegetation was dominated by broadleaved deciduous forest, together with PicealAbies forest and sclerophyllous Quercus. The dominance of coldtolerant species in the forest vegetation suggests lower winter temperatures and gradually increasing precipitation in summer.

From 11.3 to $10.4 \mathrm{cal} \mathrm{ka} \mathrm{BP}$, the decreases in herbaceous pollen, Salix and Ericaceae, and significant increases in Betula, reflect the replacement of shrubland and meadow by Betula woodland. Pinus, PicealAbies, Carpinus, deciduous and sclerophyllous Quercus were common. These changes indicate that the vegetation around Wuxu Lake gradually became closed and that the climate became more seasonal, with warmer and wetter summers and cold winters.

The gradual decrease of Betula and Carpinus, and the slight increase of Tsuga, Actinidiaceae, Rubus, Rosaceae, Potentilla, Gesneriaceae, Labiatae and Hypericum until $8.2 \mathrm{cal} \mathrm{ka} \mathrm{BP}$, indicate that the vegetation cover was closed. The deciduous broadleaved forest began to retreat and conifer and broadleaved mixed forest with Tsuga appeared within the vertical vegetation belts. Actinidiaceae and Rubus replaced Salix and Ericaceae, forming the understory. These vegetation changes indicate that the climate was very humid in summer and gradually became warmer in winter.

The continuous increase of Tsuga and sclerophyllous Quercus, and the gradual decrease of Betula and PicealAbies between 8.2 and $6.6 \mathrm{cal} \mathrm{kaBP}$, suggest that mixed forest continued to expand towards Wuxu Lake. These vegetation changes indicate that the summers were rather dry and that there was reduced seasonality of temperature.

From 6.6 to $4.9 \mathrm{cal} \mathrm{ka} \mathrm{BP}$, the relatively high representation of sclerophyllous Quercus, increased Actinidiaceae and Rubus and steadily decreasing Betula and PicealAbies suggest the presence of sclerophyllous Quercus forest with a dense understory gradually replacing deciduous broadleaved forest and PicealAbies forest. The summers were humid and the winters were warm.

Since 4.9 cal ka BP, the significantly high representation of herbaceous pollen taxa (including Artemisia, Gramineae and Cyperaceae), Hippophae and Ericaceae indicates that the regional vegetation cover became more open compared to the early Holocene. Increased sclerophyllous Quercus, Tsuga and decreased Betula suggest an expansion of Tsuga forest, accompanied by the retreat of Betula forest and a slight expansion of Carpinus forest. The summers were relatively dry

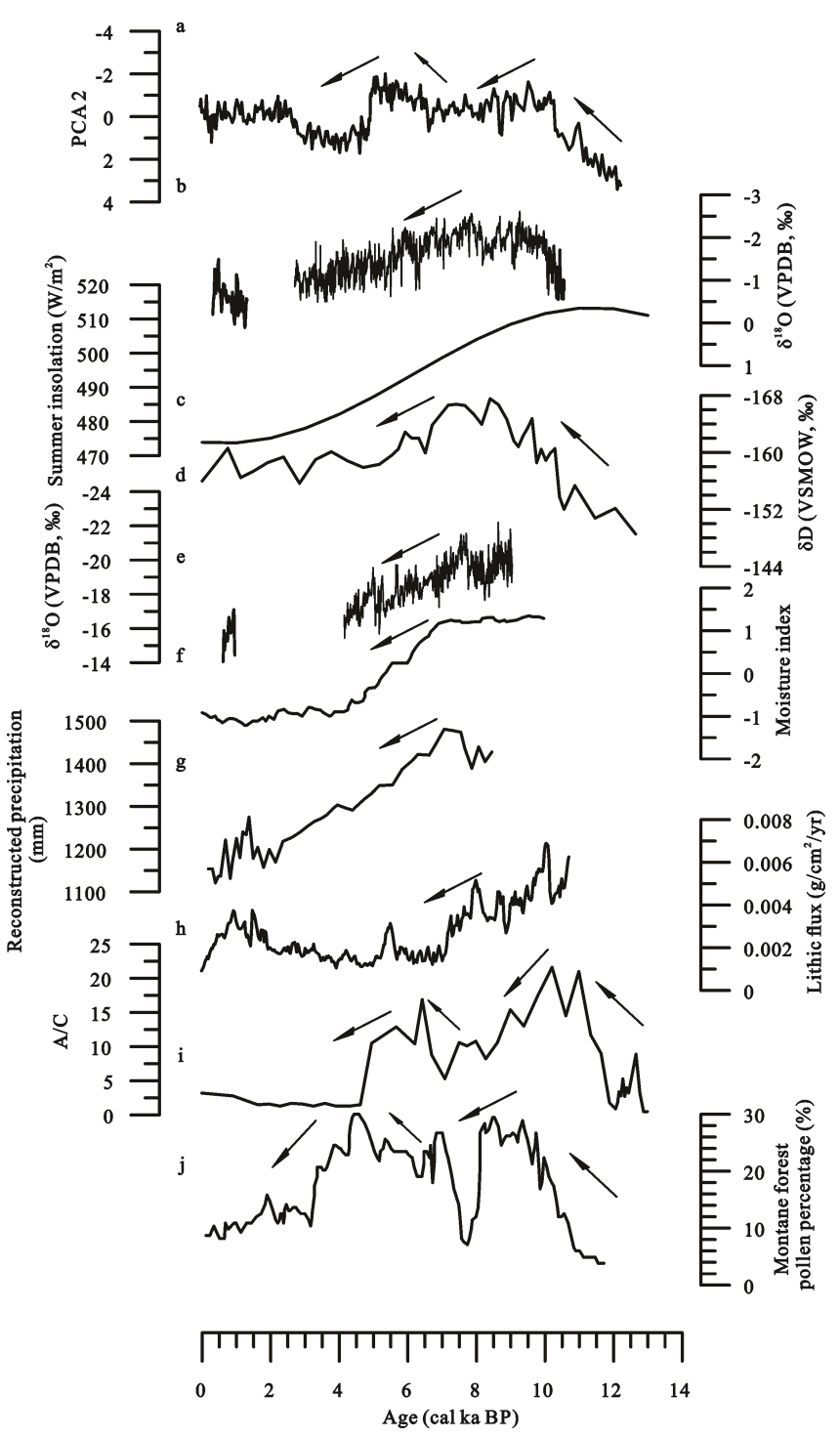

Figure 6. Sample scores on PCA axis 2 of pollen data from Wuxu Lake interpreted as a proxy for precipitation (a) and compared with other paleoclimate records. (b) Speleothem $\delta^{18} \mathrm{O}$ record from Qunf Cave in southern Oman (Fleitmann et al., 2003); (c) June insolation at $30^{\circ} \mathrm{N}$ (Berger and Loutre, 1991); (d) hydrogen isotopic record from the northern Bay of Bengal (Contreras-Rosales et al., 2014); (e) speleothem $\delta^{18} \mathrm{O}$ record from Tianmen Cave in the southern QTP (Cai et al., 2012); (f) synthesized Holocene effective moisture index from the ISM region (Wang et al., 2010); (g) annual precipitation reconstructed from pollen assemblages from Xingyun Lake in southwestern China (Chen et al., 2014); (h) record of lithic flux at Paru Co in the southern QTP (Bird et al., 2014); (i) Artemisia to Chenopodiaceae (A / C) ratio from Tso Kar in the western QTP (Demske et al., 2009); (j) montane forest pollen percentage record from Naleng Lake in the southeastern QTP (Kramer et al., 2010). 
and the winters were warmer, compared to the preceding interval.

After $2.6 \mathrm{cal}$ ka BP, Betula forest was further replaced by sclerophyllous Quercus. Tsuga and Alnus remained at a similar level as during the preceding stage. The slight decrease in Artemisia, Cyperaceae, Gramineae and Ranunculaceae indicates that the alpine meadows retreated, whiles increase in Rosaceae, Potentilla, Gesneriaceae, Labiatae and Hypericum suggests that the forest was relatively closed. With humid summers and warm winters the climate was more favorable compared to the preceding interval. The minor increase in Sanguisorba, a grazing indicator (Kramer et al., 2010), suggests the influence of human activity in the region.

\subsection{Timing of the Holocene}

The YD is the last millennial-scale cooling event before the beginning of the Holocene in the Northern Hemisphere (Stuiver et al., 1995). In the ISM region, a roughly contemporaneous cold and dry event has been observed in numerous records but in general they are of low resolution. At about 11.3 cal ka BP, the abrupt decrease of PCA 2 axis sample scores may reflect the termination of the YD cold event in the region. A high-resolution stalagmite $\delta^{18} \mathrm{O}$ record from Moomi Cave in Yemen exhibits a sharp fall at about $11.4 \mathrm{kaBP}$, marking the onset of the Holocene (Shakun et al., 2007). A pollen and stoma record from Tiancai Lake in southwestern China also suggests that the age of the termination of the YD was about $11.5 \mathrm{cal}$ ka BP (Xiao et al., 2014a). However, other records, such as pollen records from Erhai Lake and Naleng Lake (Kramer et al., 2010; J. Shen et al., 2006), and stable carbon isotope record from Muge Co (Sun et al., 2015) show relatively large uncertainties due to the bulk sediment dated. Thus the timings in the ISM region are generally consistent with the age of the YD termination in the Greenland ice core record (Stuiver et al., 1995).

Several factors may be responsible for the 200-year time lag in the Wuxu Lake record. Firstly, the stage for vegetation succession: e.g., the Abies/Picea form the climax forest in the sub-alpine ecotone after glacier retreat in northwestern Sichuan took about 100 years (Cheng and Luo, 2004). Pollen records from North America and Europe also show that vegetation may lag climate change by $100-200$ years (Williams et al., 2002). Secondly, the influence of a centennial-scale event may have hindered our pollen record to distinguish the short event as the YD (Rasmussen et al., 2006; Shakun et al., 2007). Thirdly, errors in the AMS ${ }^{14} \mathrm{C}$ dates could also be responsible for the 200-year time lag (the $95 \%$ confidence limit of the point ranges from 11.0 to $11.6 \mathrm{cal} \mathrm{ka} \mathrm{BP}$ ).

\subsection{Structure of the Holocene climatic optimum}

The onset of warm and humid conditions around Wuxu Lake occurred after $10.4 \mathrm{cal} \mathrm{ka} \mathrm{BP}$ and was maintained until $4.9 \mathrm{cal} \mathrm{kaBP}$, resulting in a prolonged Holocene Opti- mum except for a relatively cold pulse between 8.2 and $6.6 \mathrm{cal} \mathrm{kaBP}$ (Fig. 6a). The $\delta^{18} \mathrm{O}$ and $\delta \mathrm{D}$ values of rainfall reflect changes in isotopic composition in moisture source areas and by transport distance, and are not correlated with seasonal rainfall amount. However, in the ISM region these isotope ratios are suggested to reflect monsoon intensity over time spans longer than the annual scale (Breitenbach et al., 2010; Contreras-Rosales et al., 2014). High-resolution stalagmite $\delta^{18} \mathrm{O}$ records from Qunf Cave in southern Oman (Fig. 6b) and Tianmen Cave in southern QTP (Fig. 6e) indicate an interval of strong ISM in the early Holocene, followed by a progressive weakening trend at about 6-7 ka BP (Cai et al., 2012; Fleitmann et al., 2003). Records of carbonate $\delta^{18} \mathrm{O}$ and plant wax $\delta \mathrm{D}$ from lake and marine sediments, which reflect the isotopic composition of the precipitation, reveal a similar trend (Fig. 6d, Bird et al., 2014; Contreras-Rosales et al., 2014; Sarkar et al., 2015). Thus, the traditional view suggests that a warm and humid climate with a strong summer monsoon occurred during the first half of the Holocene in the ISM region (Fig. 6f, Wang et al., 2010; Zhang et al., 2011), coinciding with gradual changes in Northern Hemisphere summer insolation (Fig. 6c, Berger and Loutre, 1991). The abrupt monsoonal intensification and the early- to- mid-Holocene climatic optimum around Wuxu Lake are in accord with this view. In detail, the climatic optimum exhibits two peaks, at 10.4-8.2 and 6.6-4.9 cal ka BP, with a slight reduction between 8.2 and $6.6 \mathrm{cal}$ ka BP. However, in the ISM region only the early stage of the Holocene monsoonal maximum is well documented in paleoclimatic records with reliable age control. In the Hajjar Mountain range in northern Oman, sediment accumulation rates based on optically stimulated luminescence dating show that the early Holocene humid period began at $10.5 \mathrm{ka} \mathrm{BP}$, and reached a maximum at 9.0-8.0 ka BP (Fuchs and Buerkert, 2008). Sedimentation data from Paru Co from the southern QTP suggest that the ISM precipitation maximum occurred during the early Holocene, between 10.1 and $7.1 \mathrm{cal} \mathrm{ka} \mathrm{BP}$ (Fig. 6h, Bird et al., 2014). In addition, reconstructed monsoon precipitation based on pollen assemblages from Xingyun Lake in Southwest China reached a maximum during the interval 7.8-7.5 cal kaBP (Fig. 6g, Chen et al., 2014). This general pattern of the Holocene climatic optimum is also observed in several other records from the QTP, but is affected by the carbon reservoir effect. A pollen record from Tso Kar in northwestern India indicates a rapid increase in summer monsoon precipitation from 10.8 to $9.2 \mathrm{cal} \mathrm{ka} \mathrm{BP}$, a moderate reduction in precipitation between 9.2 and $6.8 \mathrm{cal} \mathrm{kaBP}$, and a second precipitation pulse from 6.9 and 4.8 cal ka BP (Fig. 6i, Demske et al., 2009). Similarly, the record from Lake Naleng in the southeastern QTP indicates relatively stable, warm and humid conditions from 10.7 to $4.4 \mathrm{cal} \mathrm{ka} \mathrm{BP}$, except for the interval between 8.1 and $7.2 \mathrm{cal} \mathrm{ka} \mathrm{BP}$ (Fig. 6j, Kramer et al., 2010). In addition, reconstructed total solar irradiance based on cosmogenic radionuclides indicates significantly weakened solar activity 

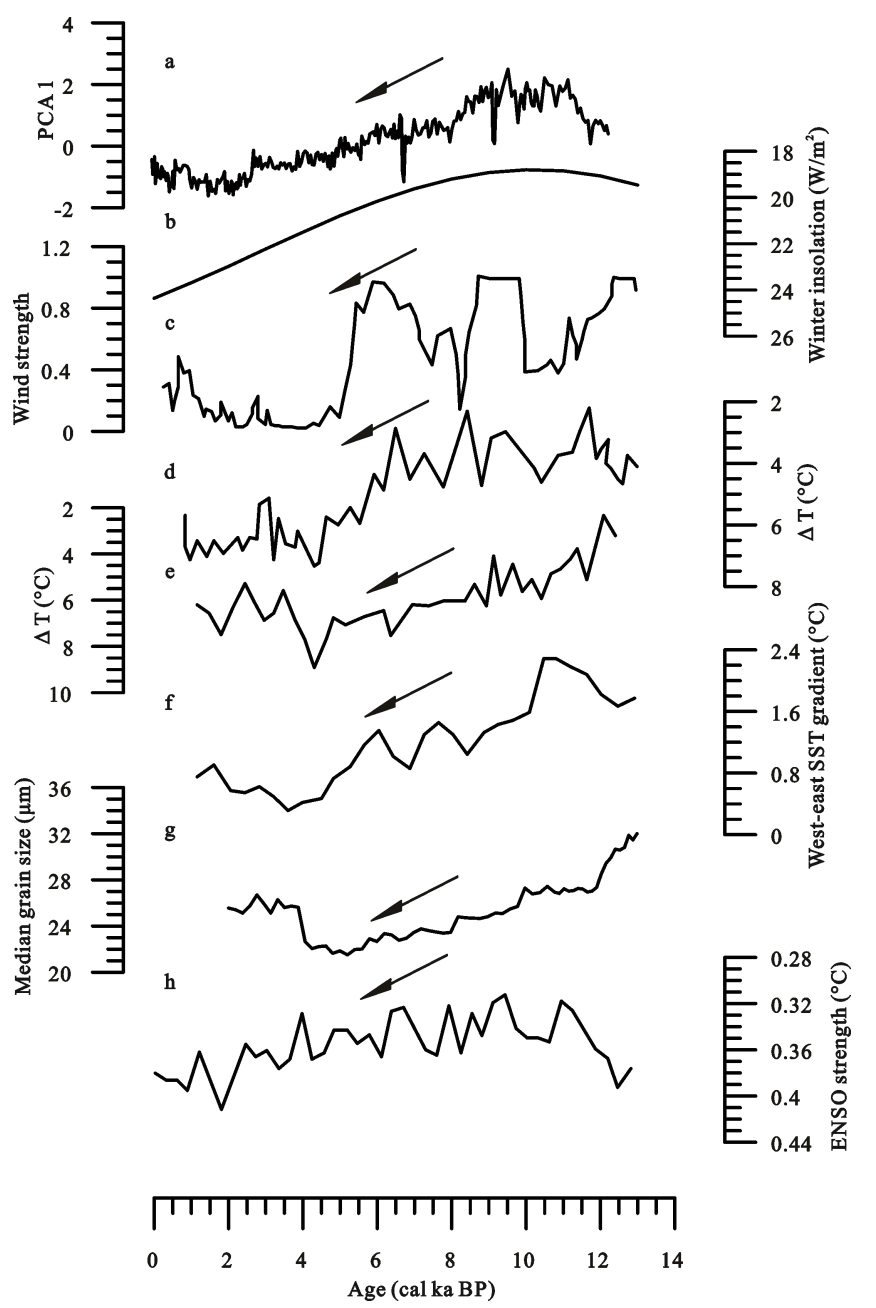

Figure 7. Sample scores on PCA axis 1 of pollen data from Wuxu Lake interpreted as a proxy for EAWM (a) and compared with other paleoclimate records. (b) December solar insolation at $60^{\circ} \mathrm{N}$ (Berger and Loutre, 1991); (c) winter wind strength record from Huguangyan Lake (Wang et al., 2012); (d) record of the Pacific Ocean thermal gradient between the surface and the thermocline from core MD05-2904 (Steinke et al., 2011); (e) record of the Pacific Ocean thermal gradient between the surface and the thermocline from core MD01-2390 (Steinke et al., 2010); (f) west-east SST gradient of the South China Sea (Huang et al., 2011); (g) grainsize record from the Jingyuan loess section (Sun et al., 2012); (h) ENSO amplitude based on a transient coupled general circulation model simulation in 300-year windows (Liu et al., 2014).

between 8 and $7 \mathrm{kaBP}$ (Steinhilber et al., 2012). Furthermore, a $\sim 90$-year periodicity in the pollen record from Wuxu Lake has also been documented in the stalagmite $\delta^{18} \mathrm{O}$ record from Qunf Cave in southern Oman (Fleitmann et al., 2003), and is close to the significant 87 -year periodicity of the $\Delta^{14} \mathrm{C}$ record (Stuiver and Braziunas, 1993). This correspondence suggests a link between solar irradiance and ISM variability during the Holocene.
Most of the records from the QTP indicate that the climate became cold and dry in the late Holocene, suggesting that the environment of the QTP and the adjacent region was predominantly influenced by the ISM (Sun et al., 2015). However, the inconsistency in the timing and duration of the Holocene climatic optimum indicates the occurrence of local variations in rainfall amount in response to the ISM (Bird et al., 2014), which is compatible with the complex terrain of the margin of the QTP. The topography effect of the Tibetan Plateau affects the moisture transfer path and establishes unstable potential energy stratification (Chen et al., 2007; Houze, 2012). The steep terrain of the margin of the QTP strengthens ascending air motions, promoting the release of latent heat and the rapid development of strong convection. Because of their high elevations, the mountains block low-level airflows to the windward sides and significantly reduce moisture transport to the interior. Until now, the long duration of the Holocene climatic optimum has only been observed in records from the margin of the QTP, suggesting that local topography and rain-shadow effects may also have played an important role in the Holocene moisture evolution of the QTP.

\subsection{Relationship between the Wuxu Lake paleovegetation record and the EAWM}

It was suggested above that the first PCA axis may reflect winter temperature. Since the winter temperature in China is negatively correlated with the intensity of the EAWM (Guo, 1994; Ren, 1990), it can be assumed that the sample scores on PCA axis 1 are a proxy for the EAWM intensity. The record from Wuxu Lake suggests that the EAWM was strong from the late YD to the early Holocene, and that it gradually weakened in the late Holocene (Fig. 7a). The overall trend of the EAWM during the past $12.3 \mathrm{ka}$ probably followed gradual changes in Northern Hemisphere winter insolation (Fig. 7b, Berger and Loutre, 1991). A strong EAWM in the early Holocene is consistent with other records from the Chinese monsoonal region. For example, the diatom record from Huguangyan Lake in southern China indicates that the water column was well mixed in the early Holocene, mainly as the result of cold, windy conditions during winter (Fig. 7c, Wang et al., 2012). This hypothesis is further supported by the records of total organic carbon content and $\delta^{15} \mathrm{~N}$ from the same lake (Jia et al., 2015). The larger sea surface temperature (SST) gradients over the South China Sea reveal a strengthened EAWM during the early Holocene (Fig. 7d to f, Huang et al., 2011; Steinke et al., 2010, 2011). However, the grain-size record of Chinese loess deposits also indicates that the EAWM winds gradually weakened from the early Holocene to the mid-Holocene, and then gradually strengthened in the late Holocene (Fig. 7g, Sun et al., 2012), a similar pattern to that recorded by geochemical parameters from Gonghe Basin in the northeastern QTP (Liu et al., 2013). The discrepancies may be due to the fact that the grain-size of loess and dune mobility were also influenced by the advance 
or retreat of deserts in northern China (Mason et al., 2008; Yang and Ding, 2008).

Interestingly, the pollen record from Wuxu Lake suggests that the EAWM was weaker in the late YD than in the early Holocene. However, this finding is in conflict with the diatom record from Huguangyan Lake, which indicates that the EAWM intensified significantly in response to abrupt climate change in the North Atlantic Ocean (Fig. 7c, Wang et al., 2012). The records from the South China Sea also indicate an intensified EAWM during this interval, in response to the slowdown of the Atlantic meridional overturning circulation (Fig. 7d to f, Huang et al., 2011; Steinke et al., 2010, 2011). However, it should be noted that the marine records are poorly dated and are of low temporal resolution. The anomaly may be explained by the climate in the tropical eastern Pacific. Observation data show that a strong EAWM usually occurs when there is a negative SST anomaly in the tropical eastern Pacific (La Niña), while a positive anomaly (El Niño) is usually accompanied by a weak EAWM (Chen et al., 2000; Wang et al., 2000). A model study indicates a significant enhancement of the El Niño-Southern Oscillation (ENSO) amplitude during the YD (Liu et al., 2014), which accords with the weak EAWM revealed by the Wuxu Lake record (Fig. 7h). Furthermore, a gradual intensification of ENSO during the Holocene also accords with a weakened EAWM, suggesting that low-latitude climate processes also played an important role in the EAWM evolution during the past $12.3 \mathrm{ka}$.

\subsection{Relationship between the EAWM and ISM}

Previous studies of the dust deposits of the Chinese Loess Plateau indicate that the winter monsoon is negatively correlated with the summer monsoon on orbital and millennial timescales (Porter, 2001; Sun et al., 2012). As mentioned above, the grain-size of loess is controlled by both the winter wind intensity and the summer precipitation. Comparison of the EAWM proxy record (Fig. 8a) with the stalagmite $\delta^{18} \mathrm{O}$ record from Qunf Cave in southern Oman (Fig. 8c, Fleitmann et al., 2003) and with the plant wax $\delta \mathrm{D}$ record from the northern Bay of Bengal (Fig. 8d, Contreras-Rosales et al., 2014), which are ISM intensity records, reveals a broadly in-phase relationship between the EAWM and ISM in the past $12.3 \mathrm{ka}$ and suggests a stronger seasonal contrast during the early Holocene than during the late Holocene. This stronger seasonal contrast during the early Holocene clearly tracks solar insolation differences between the winter and summer seasons (Fig. 8b and e, Berger and Loutre, 1991). During the Holocene, increases in winter insolation and in winter temperature at high latitudes of the Northern Hemisphere reduced the intensity of the Siberian High and resulted in a weak EAWM; however, decreased summer insolation caused the southward migration of the intertropical convergence zone and resulted in a weak ISM (Wang et al., 2012). In addition, solar insolation in the Southern Hemisphere was

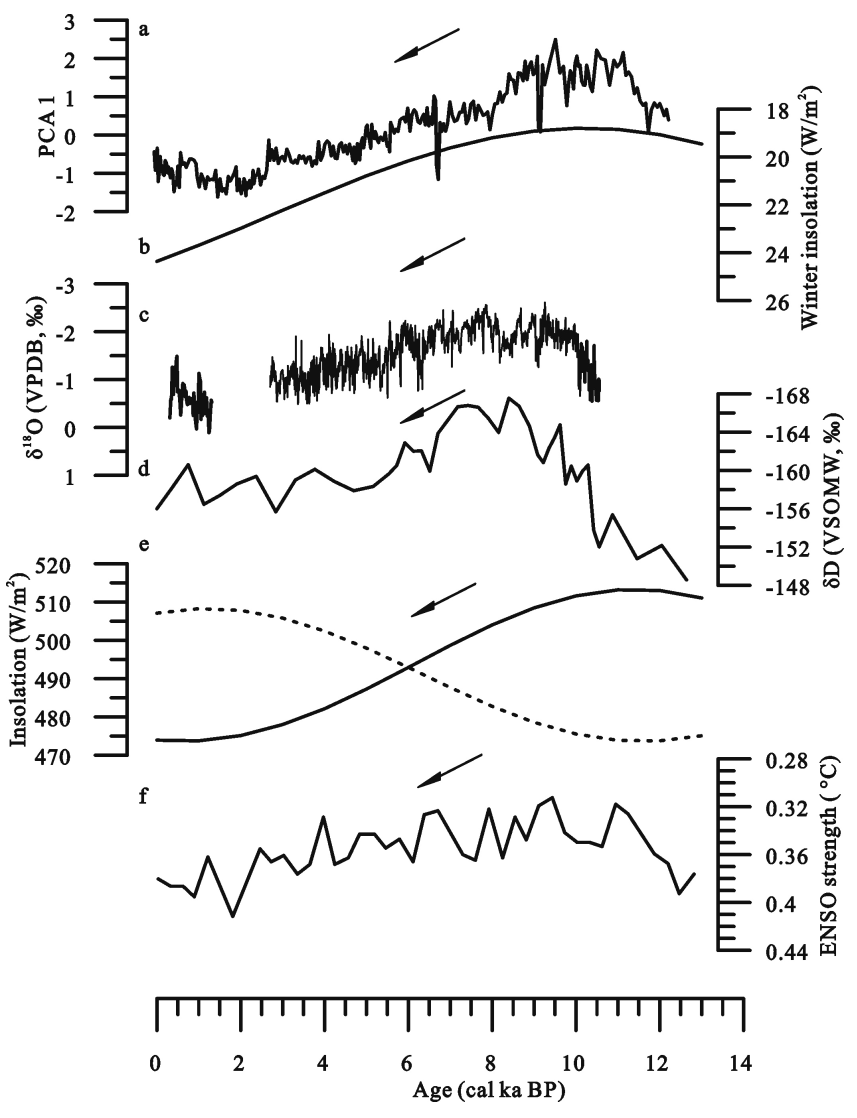

Figure 8. Comparison of the EAWM and the ISM based on proxy records. (a) Sample scores on PCA axis 1 of pollen data from Wuxu Lake; (b) December solar insolation at $60^{\circ} \mathrm{N}$ (Berger and Loutre, 1991); (c) speleothem $\delta^{18} \mathrm{O}$ record from Qunf Cave in southern Oman (Fleitmann et al., 2003); (d) hydrogen isotope record from the northern Bay of Bengal (Contreras-Rosales et al., 2014); (e) contrast of solar insolation between $30^{\circ} \mathrm{N}$ in June (solid line) and $30^{\circ} \mathrm{S}$ in December (dashed line; Berger and Loutre, 1991); (f) record of ENSO amplitude based on a transient coupled general circulation model simulation in 300-year windows (Liu et al., 2014).

relatively low and El Niño strength was relatively weak during the early Holocene (Fig. 8e and f, Berger and Loutre, 1991; Liu et al., 2014), which would probably have promoted both a strong EAWM and ISM (Chen et al., 2000; Kumar et al., 1999; Wang et al., 2000). Based on historical documents from eastern China, a relationship between the frequency of cold winters and summer rainfall during AD 700-900 further supports the notion that the strength of the winter monsoon is in-phase with the summer monsoon (Zhang and Lu, 2007).

\section{Conclusions}

We have reconstructed variations in the EAWM and ISM during the late deglaciation and the Holocene based on a well-dated pollen record from Wuxu Lake in southwestern 
China. Our findings are generally consistent with previous studies: the EAWM was strong in the early Holocene and weakened in the late Holocene. However, in contrast to other studies, our results suggest that the EAWM was slightly weaker during the YD event than in the early Holocene. Our record indicates that the ISM began to strengthen at about $11.3 \mathrm{cal} \mathrm{ka} \mathrm{BP}$, corresponding to the termination of the YD in the Northern Hemisphere. The Holocene climatic optimum, in terms of maximum precipitation, persisted from 10.4 to $4.9 \mathrm{cal} \mathrm{ka} \mathrm{BP}$, and we attribute this long duration on the margin of the QTP to the complex topography of the area and related orographic effects. This inconsistency in the onset and duration of the strengthened ISM may reflect a discrepancy in local rainfall response to the ISM. Overall, the EAWM is broadly in-phase with the ISM, both of which decrease in strength from the early to the late Holocene, which is caused by the interplay of solar insolation between the winter and summer seasons and ENSO strength in the tropical Pacific.

Acknowledgements. We thank two anonymous reviewers who gave us important advice which improved the quality of the paper. We also thank Jan Bloemendal for correcting the English language, and Q. Jiang and H. Tang for field assistance. This project was supported by the Strategic Priority Research Program-Climate Change: Carbon Budget and Relevant Issues of the Chinese Academy of Sciences (Grant no. XDA05120102) and NIGLAS (2012135004), and the National Natural Science Foundation of China (no. 41272380).

Edited by: J. Guiot

\section{References}

An, Z., Porter, S. C., Kutzbach, J. E., Wu, X., Liu, X., Li, X., and Zhou, W.: Asynchronous Holocene optimum of the East Asian monsoon, Quaternary Sci. Rev., 19, 743-762, 2000.

An, Z., Clemens, S. C., Shen, J., Qiang, X., Jin, Z., Sun, Y., Prell, W. L., Luo, J., Wang, S., Xu, H., Cai, Y., Zhou, W., Liu, X., Liu, W., Shi, Z., Yan, L., Xiao, X., Chang, H., Wu, F., Ai, L., and Lu, F.: Glacial-interglacial Indian Summer monsoon dynamics, Science, 333, 719-723, 2011.

Berger, A. and Loutre, M.-F.: Insolation values for the climate of the last 10 million years, Quaternary Sci. Rev., 10, 297-317, 1991.

Bird, B. W., Polisar, P. J., Lei, Y., Thompson, L. G., Yao, T., Finney, B. P., Bain, D. J., Pompeani, D. P., and Steinman, B. A.: A Tibetan lake sediment record of Holocene Indian summer monsoon variability, Earth Planet. Sc. Lett., 399, 92-102, 2014.

Blaauw, M. and Andres Christen, J.: Flexible paleoclimate agedepth models using an autoregressive gamma process, Bayesian Analysis, 6, 457-474, 2011.

Breitenbach, S. F. M., Adkins, J. F., Meyer, H., Marwan, N., Kumar, K. K., and Haug, G. H.: Strong influence of water vapor source dynamics on stable isotopes in precipitation observed in Southern Meghalaya, NE India, Earth Planet. Sc. Lett., 292, 212-220, 2010 .
Cai, Y., Zhang, H., Cheng, H., An, Z., Lawrence Edwards, R., Wang, X., Tan, L., Liang, F., Wang, J., and Kelly, M.: The Holocene Indian monsoon variability over the southern Tibetan Plateau and its teleconnections, Earth Planet. Sc. Lett., 335-336, 135-144, 2012.

Chen, F., Chen, X., Chen, J., Zhou, A., Wu, D., Tang, L., Zhang, X., Huang, X., and Yu, J.: Holocene vegetation history, precipitation changes and Indian Summer Monsoon evolution documented from sediments of Xingyun Lake, south-west China, J. Quaternary Sci., 29, 661-674, 2014.

Chen, J., Li, C., and He, G.: A diagnostic analysis of the impact of complex terrain in the eastern Tibetan Plateau, China, on a severe storm, Arct. Antarct. Alp. Res., 39, 699-707, 2007.

Chen, W., Graf, H.-F., and Huang, R.: The interannual variability of East Asian Winter Monsoon and its relation to the summer monsoon, Adv. Atmos. Sci., 17, 48-60, 2000.

Cheng, G. and Luo, J.: Succession features and dynamic simulation of subalpine forest in the Gongga Mountain, China, J. Mt. Sci., 1, 29-37, 2004.

Cheng, H., Edwards, R. L., Ho, J., Gallup, C. D., Richards, D. A., and Asmerom, Y.: The halflives of uranium-234 and thorium230, Chem. Geol., 169, 17-33, 2000.

Contreras-Rosales, L. A., Jennerjahn, T., Tharammal, T., Meyer, V., Lückge, A., Paul, A., and Schefuß, E.: Evolution of the Indian Summer Monsoon and terrestrial vegetation in the Bengal region during the past $18 \mathrm{ka}$, Quaternary Sci. Rev., 102, 133-148, 2014.

Cook, C. G., Jones, R. T., and Turney, C. S. M.: Catchment instability and Asian summer monsoon variability during the early Holocene in southwestern China, Boreas, 42, 224-235, 2013.

Demske, D., Tarasov, P. E., Wünnemann, B., and Riedel, F.: Late glacial and Holocene vegetation, Indian monsoon and westerly circulation in the Trans-Himalaya recorded in the lacustrine pollen sequence from Tso Kar, Ladakh, NW India, Palaeogeogr. Palaeocl., 279, 172-185, 2009.

Fægri, K., Kaland, P. E., and Krzywinski, K.: Textbook of Pollen Analysis, 4th edn., John Wiley and Sons, Chichester, 1989.

Fleitmann, D., Burns, S. J., Mudelsee, M., Neff, U., Kramers, J., Mangini, A., and Matter, A.: Holocene forcing of the Indian monsoon recorded in a stalagmite from southern Oman, Science, 300, 1737-1739, 2003.

Fleitmann, D., Burns, S. J., Mangini, A., Mudelsee, M., Kramers, J., Villa, I., Neff, U., Al- Subbary, A. A., Buettner, A., Hippler, D., and Matter, A.: Holocene ITCZ and Indian monsoon dynamics recorded in stalagmites from Oman and Yemen (Socotra), Quaternary Sci. Rev., 26, 170-188, 2007.

Fuchs, M. and Buerkert, A.: A 20 ka sediment record from the Hajar Mountain range in N-Oman, and its implication for detecting arid-humid periods on the southeastern Arabian Peninsula, Earth Planet. Sc. Lett., 265, 546-558, 2008.

Grimm, E. C.: CONISS: a FORTRAN 77 program for stratigraphically constrained cluster analysis by the method of incremental sum of squares, Comput. Geosci., 13, 13-35, 1987.

Guo, Q.: Relationship between the variations of East Asian winter monsoon and temperature anomalies in China, Quarterly J. Appl. Meteorol., 5, 218-225, 1994 (in Chinese).

Gupta, A. K., Anderson, D. M., and Overpeck, J. T.: Abrupt changes in the Asian southwest monsoon during the Holocene and their links to the North Atlantic Ocean, Nature, 421, 354-357, 2003. 
Hou, J., D'Andrea, W. J., and Liu, Z.: The influence of ${ }^{14} \mathrm{C}$ reservoir age on interpretation of paleolimnological records from the Tibetan Plateau, Quaternary Sci. Rev., 48, 67-79, 2012.

Houze, R. A.: Orographic effects on precipitating clouds, Rev. Geophys., 50, RG1001, doi:10.1029/2011RG000365, 2012.

Huang, E., Tian, J., and Steinke, S.: Millennial-scale dynamics of the winter cold tongue in the southern South China Sea over the past $26 \mathrm{ka}$ and the East Asian winter monsoon, Quaternary Res., 75, 196-204, 2011.

Jackson, S. and Lyford, M.: Pollen dispersal models in Quaternary plant ecology: assumptions, parameters, and prescriptions, Bot. Rev., 65, 39-75, 1999.

Jarvis, D. I.: Pollen Evidence of Changing Holocene Monsoon Climate in Sichuan Province, China, Quaternary Res., 39, 325-337, 1993.

Jia, G., Bai, Y., Yang, X., Xie, L., Wei, G., Ouyang, T., Chu, G., Liu, Z., and Peng, P. A.: Biogeochemical evidence of Holocene East Asian summer and winter monsoon variability from a tropical maar lake in southern China, Quaternary Sci. Rev., 111, 51-61, 2015

Kramer, A., Herzschuh, U., Mischke, S., and Zhang, C.: Holocene treeline shifts and monsoon variability in the Hengduan Mountains (southeastern Tibetan Plateau), implications from palynological investigations, Palaeogeogr. Palaeocl., 286, 23-41, 2010.

Kumar, K. K., Kleeman, R., Cane, M. A., and Rajagopalan, B.: Epochal changes in Indian Monsoon-ENSO precursors, Geophys. Res. Lett., 26, 75-78, 1999.

Li, J., Xu, Q., Zheng, Z., Lu, H., Luo, Y., Li, Y., Li, C., and Seppä, H.: Assessing the importance of climate variables for the spatial distribution of modern pollen data in China, Quaternary Res., 83, 287-297, 2015.

Liu, B., Jin, H., Sun, L., Sun, Z., and Su, Z.: Winter and summer monsoonal evolution in north eastern Qinghai-Tibetan Plateau during the Holocene period, Chem. Erde-Geochem., 73, 309$321,2013$.

Liu, Z., Lu, Z., Wen, X., Otto-Bliesner, B. L., Timmermann, A., and Cobb, K. M.: Evolution and forcing mechanisms of El Niño over the past 21000 years, Nature, 515, 550-553, 2014.

Maher, B. A.: Holocene variability of the East Asian summer monsoon from Chinese cave records: a re-assessment, Holocene, 18, 861-866, 2008.

Maher, B. A. and Thompson, R.: Oxygen isotopes from Chinese caves: records not of monsoon rainfall but of circulation regime, J. Quaternary Sci., 27, 615-624, 2012.

Mason, J. A., Swinehart, J. B., Lu, H., Miao, X., Cha, P., and Zhou, Y.: Limited change in dune mobility in response to a large decrease in wind power in semi-arid northern China since the 1970s, Geomorphology, 102, 351-363, 2008.

Pausata, F. S. R., Battisti, D. S., Nisancioglu, K. H., and Bitz, C. M.: Chinese stalagmite $\delta^{18} \mathrm{O}$ controlled by changes in the Indian monsoon during a simulated Heinrich event, Nat. Geosci., 4, 474-480, 2011.

Porter, S. C.: Chinese loess record of monsoon climate during the last glacial-interglacial cycle, Earth-Sci. Rev., 54, 115-128, 2001.

Prasad, S., Anoop, A., Riedel, N., Sarkar, S., Menzel, P., Basavaiah, N., Krishnan, R., Fuller, D., Plessen, B., Gaye, B., Röhl, U., Wilkes, H., Sachse, D., Sawant, R., Wiesner, M. G., and Stebich, M.: Prolonged monsoon droughts and links to Indo-Pacific warm pool: a Holocene record from Lonar Lake, central India, Earth Planet. Sc. Lett., 391, 171-182, 2014.

R Development Core Team: R: a Language and Environment for Statistical Computing, R Foundation for Statistical Computing, Vienna, Austria, 2013.

Rashid, H., Flower, B. P., Poore, R. Z., and Quinn, T. M.: A 25 ka Indian Ocean monsoon variability record from the Andaman Sea, Quaternary Sci. Rev., 26, 2586-2597, 2007.

Rasmussen, S. O., Andersen, K. K., Svensson, A. M., Steffensen, J. P., Vinther, B. M., Clausen, H. B., Andersen, M. L., Johnsen, S. J., Larsen, L. B., Bigler, M., Röthlisberger, R., Fischer, H., GotoAzuma, K., Hansson, M. E., and Ruth, U.: A new Greenland ice core chronology for the last glacial termination, J. Geophys. Res.-Atmos., 111, D06102, doi:10.1029/2005JD006079, 2006.

Reimer, P. J., Bard, E., Bayliss, A., Beck, J. W., Blackwell, P. G., Ramsey, C. B., Buck, C. E., Cheng, H., Edwards, R. L., and Friedrich, M.: IntCal13 and Marine13 radiocarbon age calibration curves 0-50 000 years cal BP, Radiocarbon, 55, 1869-1887, 2013.

Ren, G.: Winter monsoon and air temperature over East Asia region, Sci. Geogr. Sin., 10, 257-263, 1990 (in Chinese).

Sarkar, S., Prasad, S., Wilkes, H., Riedel, N., Stebich, M., Basavaiah, N., and Sachse, D.: Monsoon source shifts during the drying mid-Holocene: biomarker isotope based evidence from the core "monsoon zone" (CMZ) of India, Quaternary Sci. Rev., 123, 144-157, 2015.

Schulz, M. and Mudelsee, M.: REDFIT: estimating red-noise spectra directly from unevenly spaced paleoclimatic time series, Comput. Geosci., 28, 421-426, 2002.

Shakun, J. D., Burns, S. J., Fleitmann, D., Kramers, J., Matter, A., and Al-Subary, A.: A highresolution, absolute-dated deglacial speleothem record of Indian Ocean climate from Socotra Island, Yemen, Earth Planet. Sc. Lett., 259, 442-456, 2007.

Shen, C., Liu, K.-B., Tang, L., and Overpeck, J. T.: Quantitative relationships between modern pollen rain and climate in the Tibetan Plateau, Rev. Palaeobot. Palyno., 140, 61-77, 2006.

Shen, J., Liu, X., Wang, S., and Ryo, M.: Palaeoclimatic changes in the Qinghai Lake area during the last 18000 years, Quaternary Int., 136, 131-140, 2005.

Shen, J., Jones, R. T., Yang, X., Dearing, J. A., and Wang, S.: The Holocene vegetation history of Lake Erhai, Yunnan province southwestern China: the role of climate and human forcings, Holocene, 16, 265-276, 2006.

Shen, J., Wu, X., Zhang, Z., Gong, W., He, T., Xu, X., and Dong, H.: Ti content in Huguangyan maar lake sediment as a proxy for monsoon-induced vegetation density in the Holocene, Geophys. Res. Lett., 40, 5757-5763, 2013.

Song, X.-Y., Yao, Y.-F., Wortley, A. H., Paudayal, K. N., Yang, S.H., Li, C.-S., and Blackmore, S.: Holocene vegetation and climate history at Haligu on the Jade Dragon Snow Mountain, Yunnan, SW China, Climatic Change, 113, 841-866, 2012.

Steinhilber, F., Abreu, J. A., Beer, J., Brunner, I., Christl, M., Fischer, H., Heikkilä, U., Kubik, P.W., Mann, M., and McCracken, K. G.: 9400 years of cosmic radiation and solar activity from ice cores and tree rings, P. Natl. Acad. Sci. USA, 109, 5967-5971, 2012.

Steinke, S., Mohtadi, M., Groeneveld, J., Lin, L.-C., Löwemark, L., Chen, M.-T., and Rendle-Bühring, R.: Reconstructing the southern South China Sea upper water column structure since 
the Last Glacial Maximum: implications for the East Asian winter monsoon development, Paleoceanography, 25, PA2219, doi:10.1029/2009PA001850, 2010.

Steinke, S., Glatz, C., Mohtadi, M., Groeneveld, J., Li, Q., and Jian, Z.: Past dynamics of the East Asian monsoon: no inverse behaviour between the summer and winter monsoon during the Holocene, Global Planet. Change, 78, 170-177, 2011.

Stevens, T., Thomas, D. S. G., Armitage, S. J., Lunn, H. R., and Lu, H.: Reinterpreting climate proxy records from late Quaternary Chinese loess: a detailed OSL investigation, Earth-Sci. Rev., 80, 111-136, 2007.

Stuiver, M. and Braziunas, T. F.: Sun, ocean, climate and atmospheric ${ }^{14} \mathrm{CO}_{2}$ : an evaluation of causal and spectral relationships, Holocene, 3, 289-305, 1993.

Stuiver, M., Grootes, P. M., and Braziunas, T. F.: The GISP2 $\delta^{18} \mathrm{O}$ climate record of the past 16,500 years and the role of the sun, ocean, and volcanoes, Quaternary Res., 44, 341-354, 1995.

Sugita, S.: Pollen representation of vegetation in quaternary sediments: theory and method in patchy vegetation, J. Ecol., 82, 881897, 1994.

Sun, W., Zhang, E., Jones, R. T., Liu, E., and Shen, J.: Asian summer monsoon variability during the late glacial and Holocene inferred from the stable carbon isotope record of black carbon in the sediments of Muge Co, southeastern Tibetan Plateau, China, Holocene, 25, 1857-1868, 2015.

Sun, Y., Clemens, S. C., Morrill, C., Lin, X.,Wang, X., and An, Z.: Influence of Atlantic meridional overturning circulation on the East Asian winter monsoon, Nat. Geosci., 5, 46-49, 2012.

Tan, M.: Circulation effect: response of precipitation $\delta^{18} \mathrm{O}$ to the ENSO cycle in monsoon regions of China, Clim. Dynam., 42, 1067-1077, 2014.

ter Braak, C. J. F. and Milauer, P.: CANOCO Reference Manual and Cano-Draw for Windows User's Guide: Software for Canonical Community Ordination (Version, 4.5), Microcomputer Power, Ithaca, 2002.

Tian, J., Huang, E., and Pak, D. K.: East Asian winter monsoon variability over the last glacial cycle: insights from a latitudinal sea-surface temperature gradient across the South China Sea, Palaeogeogr. Palaeocl., 292, 319-324, 2010.

Wang, B., Wu, R., and Fu, X.: Pacific-East Asian teleconnection: how does ENSO affect East Asian climate?, J. Climate, 13, 1517-1536, 2000.

Wang, L., Li, J., Lu, H., Gu, Z., Rioual, P., Hao, Q., Mackay, A. W., Jiang, W., Cai, B., Xu, B., Han, J., and Chu, G.: The East Asian winter monsoon over the last 15,000 years: its links to high-latitudes and tropical climate systems and complex correlation to the summer monsoon, Quaternary Sci. Rev., 32, 131-142, 2012.

Wang, Y., Liu, X., and Herzschuh, U.: Asynchronous evolution of the Indian and East Asian Summer Monsoon indicated by Holocene moisture patterns in monsoonal central Asia, EarthSci. Rev., 103, 135-153, 2010.
Wang, Y. J., Cheng, H., Edwards, R. L., An, Z. S., Wu, J. Y., Shen, C.-C., and Dorale, J. A.: A high-resolution absolute-dated late Pleistocene monsoon record from Hulu Cave, China, Science, 294, 2345-2348, 2001.

Williams, J. W., Post, D. M., Cwynar, L. C., Lotter, A. F., and Levesque, A. J.: Rapid and widespread vegetation responses to past climate change in the North Atlantic region, Geology, 30, 971-974, 2002.

Wischnewski, J., Kramer, A., Kong, Z., Mackay, A. W., Simpson, G. L., Mischke, S., and Herzschuh, U.: Terrestrial and aquatic responses to climate change and human impact on the southeastern Tibetan Plateau during the past two centuries, Glob. Change Biol., 17, 3376-3391, 2011.

Wu, Z., Hou, X., and Zhu, Y.: Chinese Vegetation, Science Press, Beijing, 1980 (in Chinese).

Xiao, X., Shen, J., and Wang, S.: Spatial variation of modern pollen from surface lake sediments in Yunnan and southwestern Sichuan Province, China, Rev. Palaeobot. Palyno., 165, 224-234, 2011.

Xiao, X., Haberle, S. G., Shen, J., Yang, X., Han, Y., Zhang, E., and Wang, S.: Latest Pleistocene and Holocene vegetation and climate history inferred from an alpine lacustrine record, northwestern Yunnan Province, southwestern China, Quaternary Sci. Rev., 86, 35-48, 2014a.

Xiao, X., Haberle, S. G., Yang, X., Shen, J., Han, Y., and Wang, S.: New evidence on deglacial climatic variability from an alpine lacustrine record in northwestern Yunnan Province, southwestern China, Palaeogeogr. Palaeocl., 406, 9-21, 2014b.

Yancheva, G., Nowaczyk, N. R., Mingram, J., Dulski, P., Schettler, G., Negendank, J. F. W., Liu, J., Sigman, D. M., Peterson, L. C., and Haug, G. H.: Influence of the intertropical convergence zone on the East Asian monsoon, Nature, 445, 74-77, 2007.

Yang, S. and Ding, Z.: Advance-retreat history of the East-Asian summer monsoon rainfall belt over northern China during the last two glacial-interglacial cycles, Earth Planet. Sc. Lett., 274, 499-510, 2008.

Yu, G., Tang, L., Yang, X., Ke, X., and Harrison, S. P.: Modern pollen samples from alpine vegetation on the Tibetan Plateau, Global Ecol. Biogeogr., 10, 503-519, 2001.

Zhang, D. E. and Lu, L.: Anti-correlation of summer/winter monsoons?, Nature, 450, E7-E8, 2007.

Zhang, J., Chen, F., Holmes, J. A., Li, H., Guo, X., Wang, J., Li, S., Lü, Y., Zhao, Y., and Qiang, M.: Holocene monsoon climate documented by oxygen and carbon isotopes from lake sediments and peat bogs in China: a review and synthesis, Quaternary Sci. Rev., 30, 1973-1987, 2011.

Zhou, H., Wang, B.-S., Guan, H., Lai, Y.-J., You, C.-F., Wang, J., and Yang, H.-J.: Constraints from strontium and neodymium isotopic ratios and trace elements on the sources of the sediments in Lake Huguang Maar, Quaternary Res., 72, 289-300, 2009. 